\title{
The extreme year-analysis of thermal conditions in Poland in 2018
}

\author{
Arkadiusz M. Tomczyk ${ }^{1}$ (D) $\cdot$ Ewa Bednorz ${ }^{1}$
}

Received: 2 May 2019 / Accepted: 1 August 2019/Published online: 14 August 2019

(C) The Author(s) 2019

\begin{abstract}
The study objective was the determination of thermal conditions in Poland in 2018 on the background of the multi-annual period 1966-2018. The study was based on data obtained from the Institute of Meteorology and Water Management - National Research Institute. The research showed a statistically significant increase in mean daily air temperature in the years 19662018. The highest mean annual air temperature over the prevailing area in the analysed multi-annual period was recorded in 2018. In that year, mean air temperature was lower than the mean value from the multi-annual period only during 2 months (February and March). The highest anomalies of mean monthly air temperature were observed in April.
\end{abstract}

\section{Introduction}

In the majority of data sets, years 2014, 2015, and 2016 set new global records of heat since the commencement of regular meteorological measurements (Rahmstorf et al. 2017). As emphasised by some authors, the situation was unprecedented, because three record years in a row had never occurred before. Kolendowicz et al. (2019) analysing thermal conditions in Poznań (Poland) in the years 1848-2016 evidenced that 7 out of 10 warmest years occurred in the twenty-first century, and the warmest year was 2014. According to NOAA (2019), in the years 1880-2018 at the global scale, 9 out of 10 warmest years are those after the year 2000, with a maximum in 2016 (mean anomaly $0.95^{\circ} \mathrm{C}$ ). Year 2018 was classified on the fourth position, with mean anomalies at a level of $0.79^{\circ} \mathrm{C}$.

The observed warming is manifested in among others increasingly frequent occurrence of intensive heat waves. Cases of such waves were observed in 2003 and 2006 in West and South Europe (Rebetez et al. 2009; Muthers et al. 2017), in

Electronic supplementary material The online version of this article (https://doi.org/10.1007/s00704-019-02968-9) contains supplementary material, which is available to authorized users.

Arkadiusz M. Tomczyk

atomczyk@amu.edu.pl

1 Department of Climatology, Institute of Physical Geography and Environmental Planning, Adam Mickiewicz University in Poznań, B. Krygowskiego 10, 61-680 Poznań, Poland
2010 in East Europe (Dole et al. 2011; Grumm 2011; Otto et al. 2012), and in 1994 and 2015 in Central Europe (Hoy et al. 2017; Muthers et al. 2017; Tomczyk and Bednorz 2019). Each of the aforementioned waves caused a considerable increase in the number of deaths (Kuchcik 2001; Gabriel and Endlicher 2011), but also serious losses among others in tourism and energy engineering (de Bono et al. 2004; UNWTO - World Tourism Organization 2008; García-Herrera et al. 2010). In spite of the observed warming, several-day-long periods with very low air temperature in the winter season are still recorded. This is exemplified by the considerable cooling in Central Europe (including Poland), in January 2016 and 2017 and in February 2018 (Report of the Government Centre for Security 2016, 2017, 2018). A similar cold episode was also recorded on the Balkan Peninsula in the first half of January 2017 (Anagnostopoulou et al. 2017; Deniz and Uslan 2018). Like in the case of heat waves, considerable drops in air temperature, however short, also had serious social and economic consequences (Anagnostopoulou et al. 2017).

A further increase in temperature is expected in the following decades. It will be the most intensive in the winter season, which corresponds with the currently observed warming. The changes in the territory of Poland are forecasted to reach even $4.3{ }^{\circ} \mathrm{C}$ in the years $2071-2100$ according to the RCP 8.5 scenario (Piniewski et al. 2017). Numerous studies also showed that heat waves in Europe will be not only more frequent, but also more intensive (Meehl and Tebaldi 2004; Zacharias et al. 2015; Muthers et al. 2017). According to such forecasts, extreme heat waves similar to the "mega heat waves" from 2003 and 2010 (Barriopedro et al. 2011) will be also recorded in Poland in the foreseeable future. 
As mentioned above, year 2018 was the fourth warmest year at the global scale. Weather conditions in Poland and Europe also often appeared in mass media communications due to frosts in the beginning of the year and followed by long period of high temperatures and low precipitation. Considering the above facts, the objective of the study was the assessment of thermal conditions in Poland in 2018 on the background of the years 1966-2018. The analysis covered both mean monthly and daily conditions.

\section{Research area, data, and methods}

The study was based on daily values of mean air temperature obtained for 40 stations in Poland (Fig. 1). The data were provided by the Institute of Meteorology and Water Management - National Research Institute (IMGW-PIB), and covered the period 1966-2018.

First, mean annual and mean monthly air temperature was calculated for particular years. Then, annual and monthly air temperature anomalies were calculated. Moreover, daily air temperature anomalies were computed for each day of the year 2018. The anomalies were calculated as the difference between mean value of air temperature in a particular year, month, and day, and the mean value in such periods in the multi-annual period 1981-2010. The adopted period of reference is recommended by the World Meteorological Organization (WMO) which recommends adopting the most valid period of 30 years for climatological studies (finishing in a year ending with 0 ). Tendencies of air temperature fluctuations were determined by means of linear regression, and the significance of trends was verified by means of a Student $t$ test at a level of 0.05 .

Then, based on daily air temperature anomalies, periods with the highest and lowest anomalies in 2018 were determined. The synoptic situation was analysed for the designated periods based on weather maps provided by IMGW-PIB.

\section{Results}

In the years 1966-2018, mean annual air temperature in Poland was $7.8^{\circ} \mathrm{C}$, and its increase occurred from the northeast to south-west and west (Table 1). The described spatial distribution was disturbed in mountain areas, where terrain elevation above sea level is a factor considerably modifying thermal conditions. The lowest mean annual air temperature was observed in areas located the highest, i.e., Kasprowy Wierch and Śnieżka, at a level of $-0.3{ }^{\circ} \mathrm{C}$ and $1{ }^{\circ} \mathrm{C}$, respectively. Outside mountain areas, mean annual air temperature varied from $6.7{ }^{\circ} \mathrm{C}$ in Suwałki to $9.2{ }^{\circ} \mathrm{C}$ in Stubice. In the analysed multi-annual period, throughout the study area, a statistically significant increase in mean annual air temperature was recorded, and the most intensive changes were observed in Wrocław $\left(0.44{ }^{\circ} \mathrm{C} / 10\right.$ years $)$. On the background of the multi-annual period, high air temperature was particularly observed in the period from the beginning of the twenty-first century. Within the last 19 years, only year 2010 was
Fig. 1 Location of meteorological stations

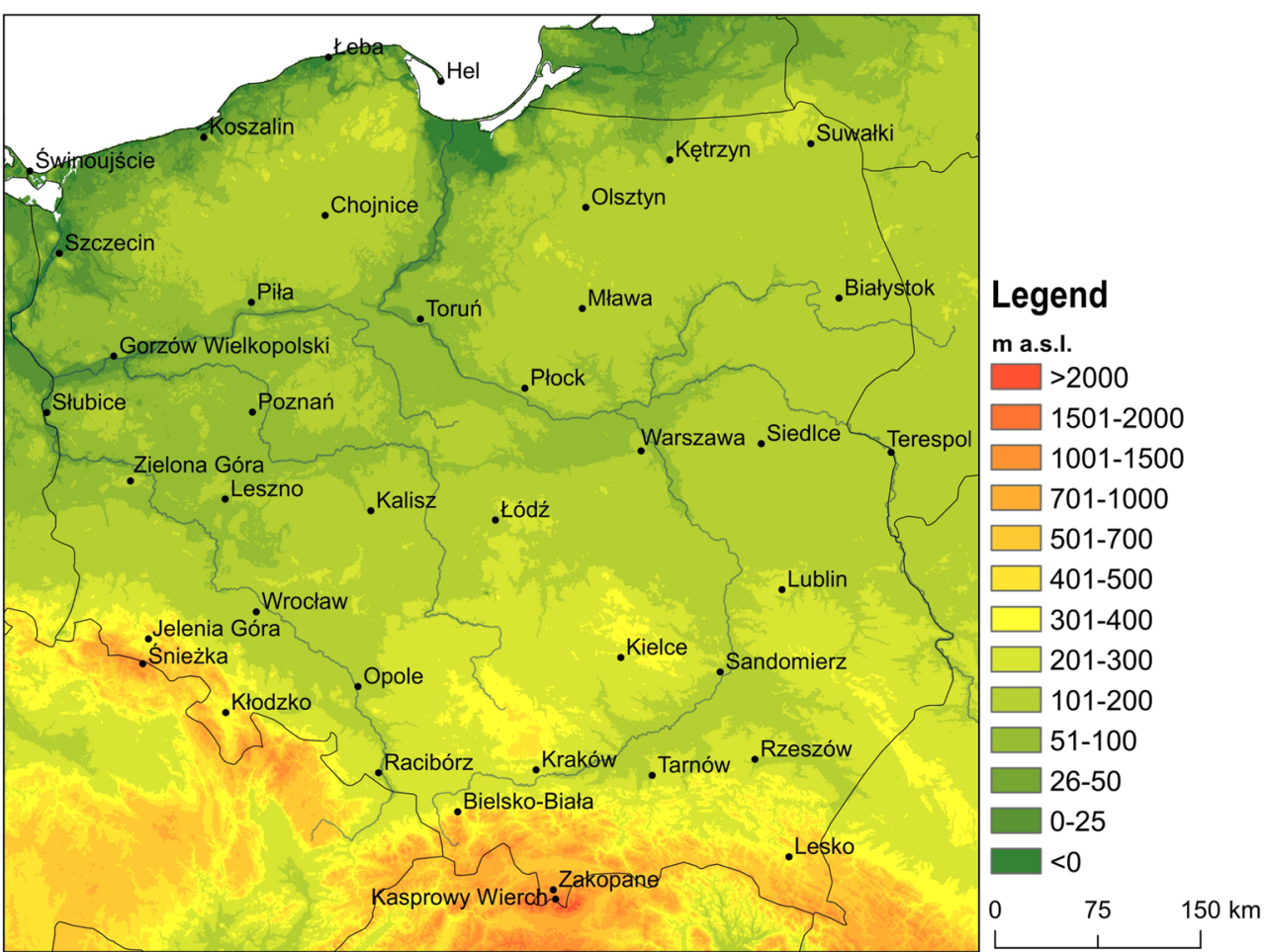


Table 1 Characteristics of thermal conditions in Poland in the years 1966-2018. Stations are arranged in spatial order from the north to the south

\begin{tabular}{|c|c|c|c|c|c|c|c|c|c|}
\hline \multirow[t]{2}{*}{ Station } & \multicolumn{2}{|c|}{$\begin{array}{l}\text { Mean annual air } \\
\text { temperature }\left[{ }^{\circ} \mathrm{C}\right]\end{array}$} & \multirow[t]{2}{*}{$\begin{array}{l}\text { Changes }\left[{ }^{\circ} \mathrm{C} /\right. \\
10 \text { years }]\end{array}$} & \multirow[t]{2}{*}{$\begin{array}{l}\text { Warmest } \\
\text { year }\end{array}$} & \multirow[t]{2}{*}{ Station } & \multicolumn{2}{|c|}{$\begin{array}{l}\text { Mean annual air } \\
\text { temperature }\left[{ }^{\circ} \mathrm{C}\right]\end{array}$} & \multirow[t]{2}{*}{$\begin{array}{l}\text { Changes }\left[{ }^{\circ} \mathrm{C} /\right. \\
10 \text { years }]\end{array}$} & \multirow[t]{2}{*}{$\begin{array}{l}\text { Warmest } \\
\text { year }\end{array}$} \\
\hline & $\begin{array}{l}* 1981- \\
2010\end{array}$ & $\begin{array}{l}1966- \\
2018\end{array}$ & & & & $\begin{array}{l}* 1981- \\
2010\end{array}$ & $\begin{array}{l}1966- \\
2018\end{array}$ & & \\
\hline 1. Łeba & 8.1 & 8.0 & 0.31 & 2018 & 21. Zielona Góra & 8.9 & 8.9 & 0.33 & 2018 \\
\hline 2. Hel & 8.4 & 8.4 & 0.31 & 2018 & 22. Leszno & 8.8 & 8.8 & 0.37 & 2018 \\
\hline 3. Koszalin & 8.4 & 8.3 & 0.36 & 2018 & 23. Kalisz & 8.8 & 8.8 & 0.39 & 2018 \\
\hline 4. Suwałki & 6.8 & 6.7 & 0.37 & 2015 & 24. Łódź & 8.4 & 8.3 & 0.33 & 2015 \\
\hline 5. Kętrzyn & 7.6 & 7.5 & 0.38 & 2018 & 25. Lublin & 7.8 & 7.8 & 0.29 & 2015 \\
\hline 6. Świnoujście & 8.8 & 8.7 & 0.31 & 2014 & 26. Wrocław & 9.1 & 9.1 & 0.44 & 2018 \\
\hline 7. Olsztyn & 7.6 & 7.6 & 0.32 & 2018 & 27. Jelenia Góra & 7.7 & 7.6 & 0.30 & 2018 \\
\hline 8. Chojnice & 7.7 & 7.6 & 0.36 & 2018 & 28. Kielce & 7.8 & 7.8 & 0.32 & 2018 \\
\hline 9. Szczecin & 9.1 & 9.1 & 0.32 & 2014 & 29. Śnieżka & 1.0 & 1.0 & 0.32 & 2014 \\
\hline 10. Białystok & 7.3 & 7.2 & 0.28 & 2018 & 30. Sandomierz & 8.3 & 8.3 & 0.34 & 2018 \\
\hline 11. Piła & 8.4 & 8.4 & 0.38 & 2018 & 31. Opole & 9.2 & 9.1 & 0.34 & 2018 \\
\hline 12. Mława & 7.7 & 7.7 & 0.35 & 2018 & 32. Kłodzko & 7.7 & 7.8 & 0.26 & 2018 \\
\hline 13. Toruń & 8.5 & 8.4 & 0.35 & 2018 & 33. Rzeszów & 8.4 & 8.3 & 0.38 & 2015 \\
\hline $\begin{array}{l}\text { 14. Gorzów } \\
\text { Wielkopolski }\end{array}$ & 9.0 & 8.9 & 0.36 & 2018 & 34. Kraków & 8.5 & 8.4 & 0.35 & 2018 \\
\hline 15. Płock & 8.3 & 8.4 & 0.26 & 2018 & 35. Racibórz & 8.8 & 8.8 & 0.27 & 2018 \\
\hline 16. Poznań & 8.9 & 8.9 & 0.36 & 2018 & 36. Tarnów & 8.9 & 8.9 & 0.38 & 2014 \\
\hline 17. Słubice & 9.2 & 9.2 & 0.37 & 2018 & 37. Bielsko-Biała & 8.5 & 8.5 & 0.35 & 2014 \\
\hline 18. Siedlce & 7.9 & 7.8 & 0.30 & 2015 & 38. Lesko & 7.7 & 7.7 & 0.26 & 2014 \\
\hline 19. Warszawa & 8.5 & 8.5 & 0.38 & 2018 & 39. Zakopane & 5.8 & 5.8 & 0.32 & 2014 \\
\hline 20. Terespol & 8.0 & 7.9 & 0.35 & 2015 & $\begin{array}{l}\text { 40. Kasprowy } \\
\text { Wierch }\end{array}$ & -0.3 & -0.3 & 0.31 & 2014 \\
\hline
\end{tabular}

Statistically significant (at 0.05 level) values are in italics

*Reference period

characterised by mean air temperature below the multi-annual mean value. At the scale of the entire area, the year with the highest mean air temperature in the analysed multi-annual period was 2018 , with an anomaly of $1.6^{\circ} \mathrm{C}$. Eight out of 10 warmest years occurred after 2000 . The situation was replicated in many singular stations. Namely, in $65 \%$ of the stations, 2018 was the warmest, and in the remaining stations, the year 2014 (within the mountain area and north-western area of the country) or 2015 (eastern region of the country) appeared outstandingly warm.

As evidenced above, the warmest year in the analysed multi-annual period was 2018. A detailed analysis of thermal conditions was performed for that year. Mean annual air temperature in 2018 for the entire area amounted to $9.5^{\circ} \mathrm{C}$ and was higher than the mean value from the multi-annual period by $1.6{ }^{\circ} \mathrm{C}$ (Fig. 2). An increase in mean annual air temperature occurred from the north-east to south-west (with the exception of mountain areas). As usual, its lowest values were recorded in mountain areas, and the lowlands' mean annual air temperature fluctuated from $8.2{ }^{\circ} \mathrm{C}$ in Suwałki to $11.3{ }^{\circ} \mathrm{C}$ in Wrocław. Positive anomalies of mean annual air temperature were recorded throughout the entire study area. Their values increased from the north to south of the country, with a maximum in the south-west. The lowest anomaly value was recorded in Świnoujście $\left(1.1^{\circ} \mathrm{C}\right)$, and the highest in Wrocław $\left(2.2^{\circ} \mathrm{C}\right)$ and in Warszawa $\left(2{ }^{\circ} \mathrm{C}\right)$.

In 2018 , the lowest mean monthly air temperature was recorded in February $\left(-3.7^{\circ} \mathrm{C}\right)$ and it was lower than average by $2.5^{\circ} \mathrm{C}$, while the highest in August $\left(19.9^{\circ} \mathrm{C}\right)$ and it was higher than average by $2.7^{\circ} \mathrm{C}$ (Fig. 3). Moreover, a lower than average mean air temperature was also recorded in March. Like in February, it was lower by $2.5^{\circ} \mathrm{C}$. In April, mean air temperature was higher than the multi-annual mean value by $4.6{ }^{\circ} \mathrm{C}$, and it was the month with the highest anomalies in 2018. Almost equally high anomalies were recorded in May ( $3.3{ }^{\circ} \mathrm{C}$ on average) with the highest values in northern Poland. Among months with positive anomalies, the lowest values were on average recorded in November $\left(1.3^{\circ} \mathrm{C}\right)$.

In February, the lowest mean air temperature (with the exception of mountain areas) was recorded in north-east regions of the study area, with a minimum in Suwałki $\left(-5.7^{\circ} \mathrm{C}\right)$. Considerably higher mean air temperature was observed in 
Fig. 2 Mean annual air temperature in Poland in 2018 and its anomalies

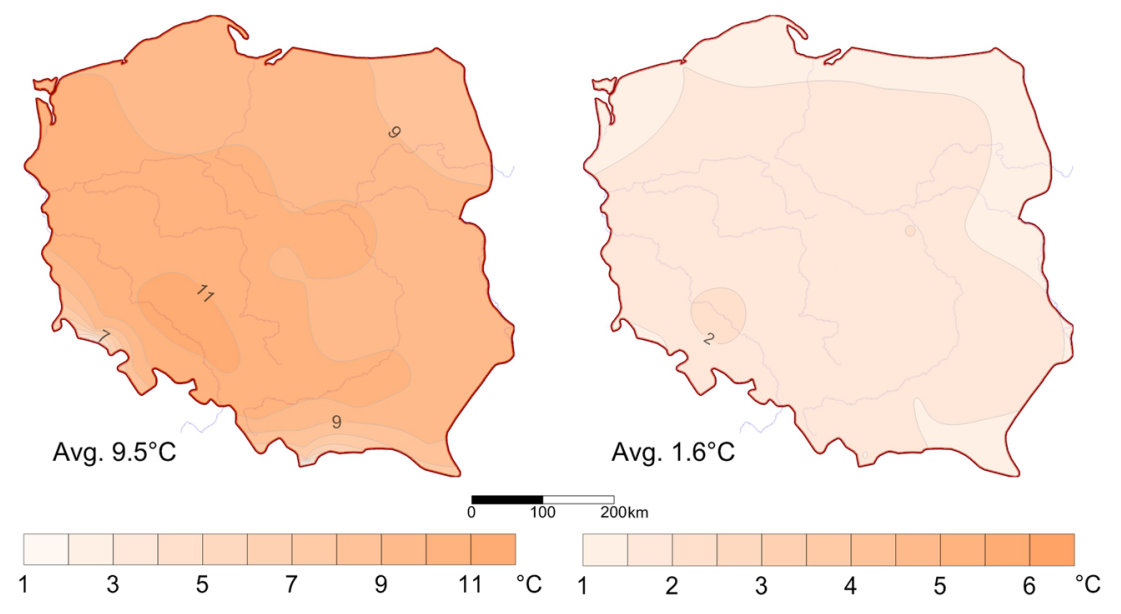

the south-east and west of the country and at the coast, with a maximum in Świnoujście $\left(-1.2^{\circ} \mathrm{C}\right)$. It was considerably colder in areas located the highest, where mean air temperature was $-11.3{ }^{\circ} \mathrm{C}$ on Kasprowy Wierch and $-10.9{ }^{\circ} \mathrm{C}$ on Śnieżka. In the aforementioned stations, the highest anomalies were also recorded, equal to $-3.1^{\circ} \mathrm{C}$ and $-4.3{ }^{\circ} \mathrm{C}$, respectively (Fig. 3). Over the major part of the country, anomalies of mean air temperature varied from -2.5 to $-3{ }^{\circ} \mathrm{C}$, and the lowest ones were observed in the east of the country with a minimum in Terespol at $-1.9^{\circ} \mathrm{C}$.

March was another month with mean air temperature lower than the multi-annual mean value. In the analysed month, mean air temperature below $0{ }^{\circ} \mathrm{C}$ (except for mountain areas) was recorded in east Poland and in Pomerania, and the minimum was observed in Suwałki $\left(-2^{\circ} \mathrm{C}\right)$. The highest mean air temperature occurred in the south-west regions of the country, with a maximum in Wrocław $\left(1.9^{\circ} \mathrm{C}\right)$ and Opole $\left(1.8^{\circ} \mathrm{C}\right)$. In mountains, mean air temperature amounted to $-7^{\circ} \mathrm{C}$ on Kasprowy Wierch and $-6.9^{\circ} \mathrm{C}$ on Śnieżka. A different spatial distribution concerned mean air temperature anomalies (Fig. 3 ). The greatest deviations from the multi-annual mean value were recorded in the north-west regions of the country, where the anomalies were $<-3{ }^{\circ} \mathrm{C}$ (in Szczecin $-3.5^{\circ} \mathrm{C}$ ). The lowest anomalies were recorded on Kasprowy Wierch at $-0.7^{\circ} \mathrm{C}$. Over a major part of the area, they varied from -2 to $-2.5^{\circ} \mathrm{C}$.

In the remaining months, mean air temperature was higher than mean value of the multi-annual period. Mean anomalies for the study area varied from $1.3{ }^{\circ} \mathrm{C}$ in November to $4.6{ }^{\circ} \mathrm{C}$ in April (Fig. 3).

Mean monthly air temperature in April increased from the north to south (with the exception of mountain areas). In the vast majority of stations at the coast, its values did not exceed $10{ }^{\circ} \mathrm{C}$, and the minimum was recorded in $\mathrm{Hel} 8.7^{\circ} \mathrm{C}$. The lowest anomalies (not exceeding $4{ }^{\circ} \mathrm{C}$ ) were observed in the same area, with a minimum in Świnoujście and Hel reaching $2.5^{\circ} \mathrm{C}$ and $2.6^{\circ} \mathrm{C}$, respectively. The highest values of mean monthly air temperature were recorded in southern Poland where over a vast majority of the area, it exceeded $14^{\circ} \mathrm{C}$, with a maximum in Tarnów at $14.7^{\circ} \mathrm{C}$. Southern Poland is also characterised by the highest anomalies, exceeding $5^{\circ} \mathrm{C}$. Their maximum value was recorded in Bielsko-Biała and Zakopane, where they reached $6{ }^{\circ} \mathrm{C}$.

The course of daily anomalies of mean air temperature in 2018 provided the basis for distinguishing several evidently colder- and warmer-than-average periods. The first one occurred at the turn of February and March (Fig. 4). Air temperature was considerably lower than on average in the multiannual period. Since 21 February to 4 March, negative anomalies of air temperature were recorded throughout the study area, and their maximum in the majority of stations occurred on 27 February. On that day, mean air temperature in Poland reached $-12.3^{\circ} \mathrm{C}$ and was lower by $12.1^{\circ} \mathrm{C}$. On the analysed day, the lowest mean air temperature was recorded on Śnieżka and Kasprowy Wierch $-21.8^{\circ} \mathrm{C}$ and $-19.4{ }^{\circ} \mathrm{C}$, respectively. In lowlands, an increase in mean air temperature occurred from the south-east and east to the north-west. In particular stations, it varied from $-16.8^{\circ} \mathrm{C}$ in Zakopane to $-6.6^{\circ} \mathrm{C}$ in Świnoujście. On that day, mean air temperature was lower than the multi-annual mean value, ranging from $8.1^{\circ} \mathrm{C}$ in Świnoujście to $15.8{ }^{\circ} \mathrm{C}$ on Śnieżka. The described cooling was caused by the persistence of a strong high pressure system over a major part of the continent, with the centre over Scandinavia (> $1055 \mathrm{hPa}$ on 27 February). The persistence of the system blocked the movement of the frontal zones from over the Atlantic and Mediterranean Sea. The aforementioned baric conditions caused advection of arctic air masses.

The first of evidently warmer periods in 2018 was observed from 7 to 25 April. In the majority of stations, the highest anomalies were recorded on 9 April (Fig. 5). On that day, mean air temperature in the study area was $14.9^{\circ} \mathrm{C}$ and was higher than average by $9.3^{\circ} \mathrm{C}$. The lowest mean air temperature was recorded on Kasprowy Wierch $\left(4.5^{\circ} \mathrm{C}\right)$ and on Śnieżka $\left(7.3^{\circ} \mathrm{C}\right)$. Outside mountain areas, mean air temperature increased from the north-west and west to the south-east 
Fig. 3 Mean monthly anomalies of air temperature in Poland in 2018
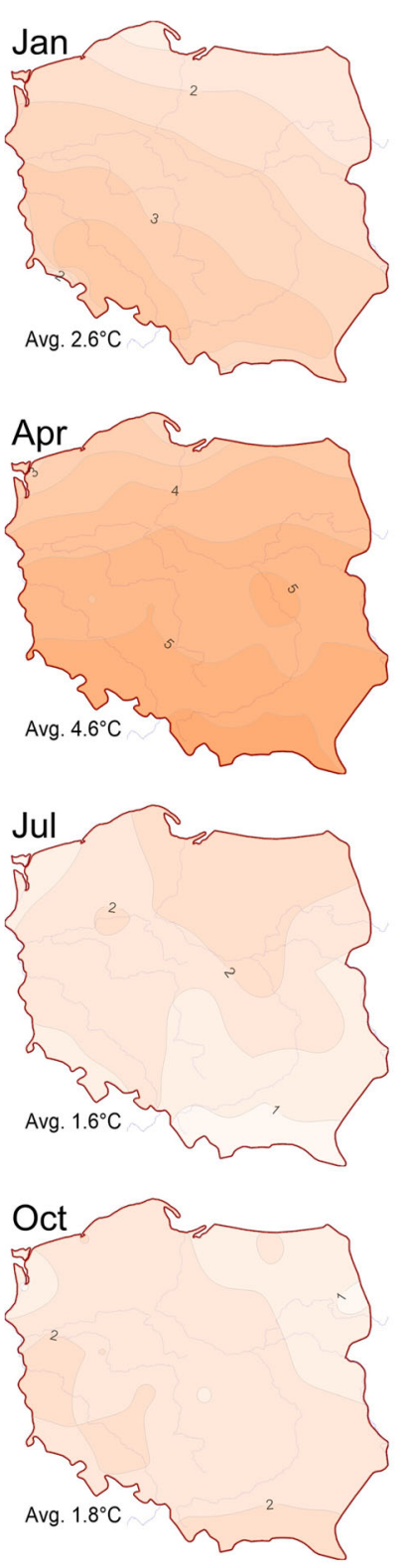

of the country. In particular stations, it varied from $9.1^{\circ} \mathrm{C}$ in Świnoujście to $20.4{ }^{\circ} \mathrm{C}$ in Tarnów. In the aforementioned stations, the lowest and highest anomalies were also recorded, equalling $3.7^{\circ} \mathrm{C}$ and $12.5^{\circ} \mathrm{C}$, respectively. In the first decade of April, high pressure systems dominated over a major part of the continent. Such baric conditions caused not only advection of polar-maritime air masses, but also strong inflow of solar radiation with small or no cloud cover. On 9 April, Poland was under the influence of a high from over west Russia, and local low from over south Germany, which guaranteed advection of warm masses of polar-maritime air from the south.
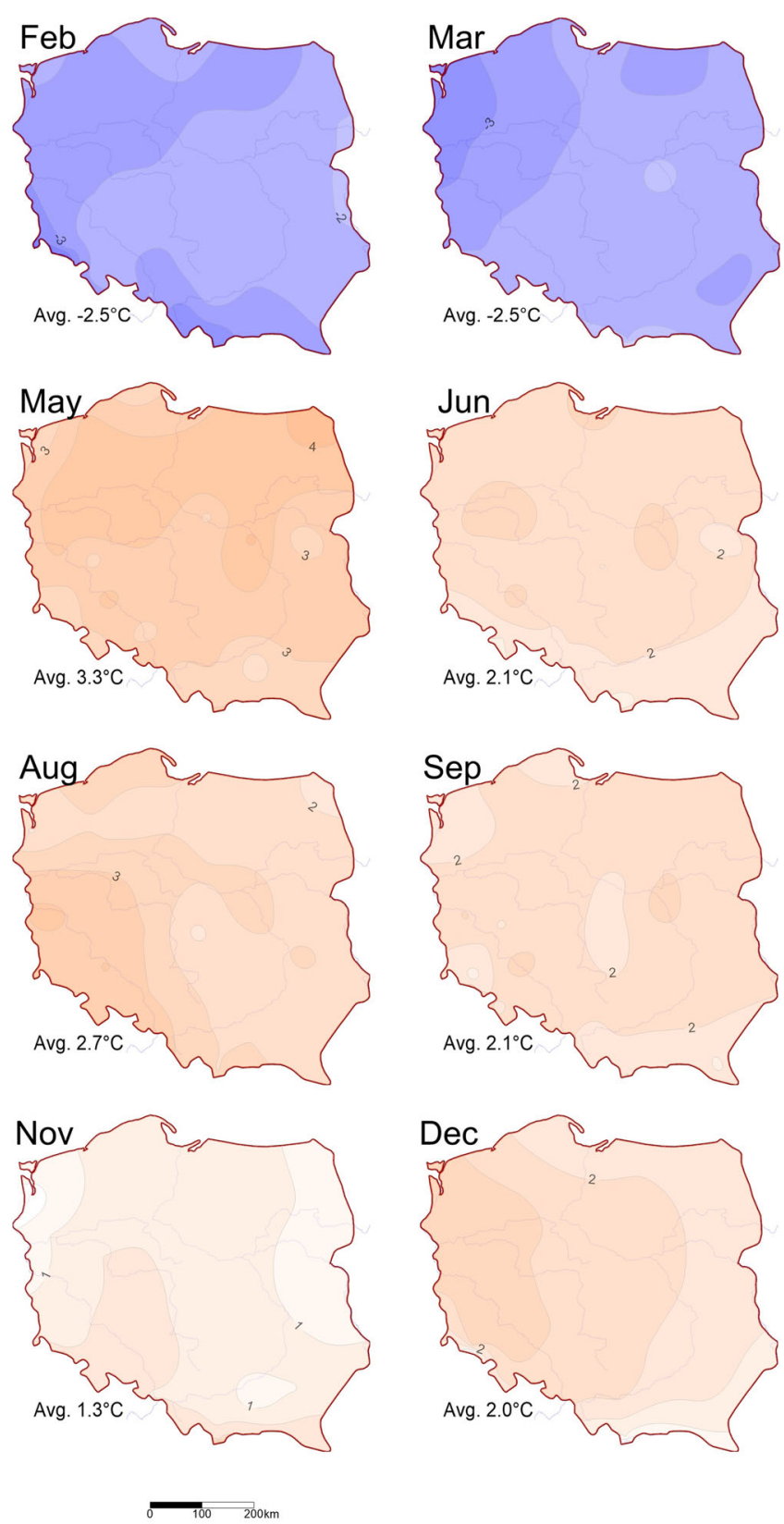

$\begin{array}{lllllllllllll}-5 & -4 & -3 & -2 & -1 & 0 & 1 & 2 & 3 & 4 & 5 & 6 & { }^{\circ} \mathrm{C}\end{array}$

The second evidently warmer-than-normal period occurred from 30 October to 15 November (Fig. 6). In the majority of stations, the optimum of the period was observed on the day of its commencement. On the same day, mean daily air temperature in the analysed area was $14.9{ }^{\circ} \mathrm{C}$ and was higher than average by $9.4{ }^{\circ} \mathrm{C}$. In mountain stations, it was $4.6{ }^{\circ} \mathrm{C}$ on Kasprowy Wierch and $4.8{ }^{\circ} \mathrm{C}$ on Śnieżka. Outside mountain areas, the lowest values of mean air temperature were recorded in the north-east regions of the country, and the highest in the southern regions. In particular stations, it varied from $10.8^{\circ} \mathrm{C}$ in Suwałki to $17.9{ }^{\circ} \mathrm{C}$ in Tarnów. More than $17{ }^{\circ} \mathrm{C}$ was also 
Fig. 4 Anomalies of mean daily air temperature from 21 February to 5 March (a; numbers of stations in accordance with numbers of stations in Table 1, arranged from northern to southern location), mean daily air temperature on 27 February (b) and its anomalies (c), and weather situation on 27 February (d); PA, arctic air mass; PPm, polar-maritime air mass; PPk, polar-continental air mass; $\mathrm{PZ}$, tropical air mass; W, atmospheric high; N, atmospheric low. Source of weather maps: Institute of Meteorology and Water Management - National Research Institute (a)

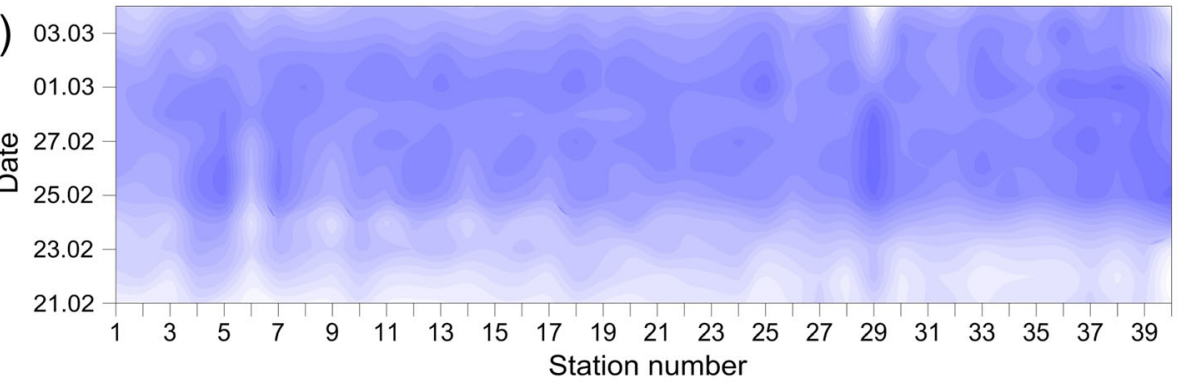

(b)

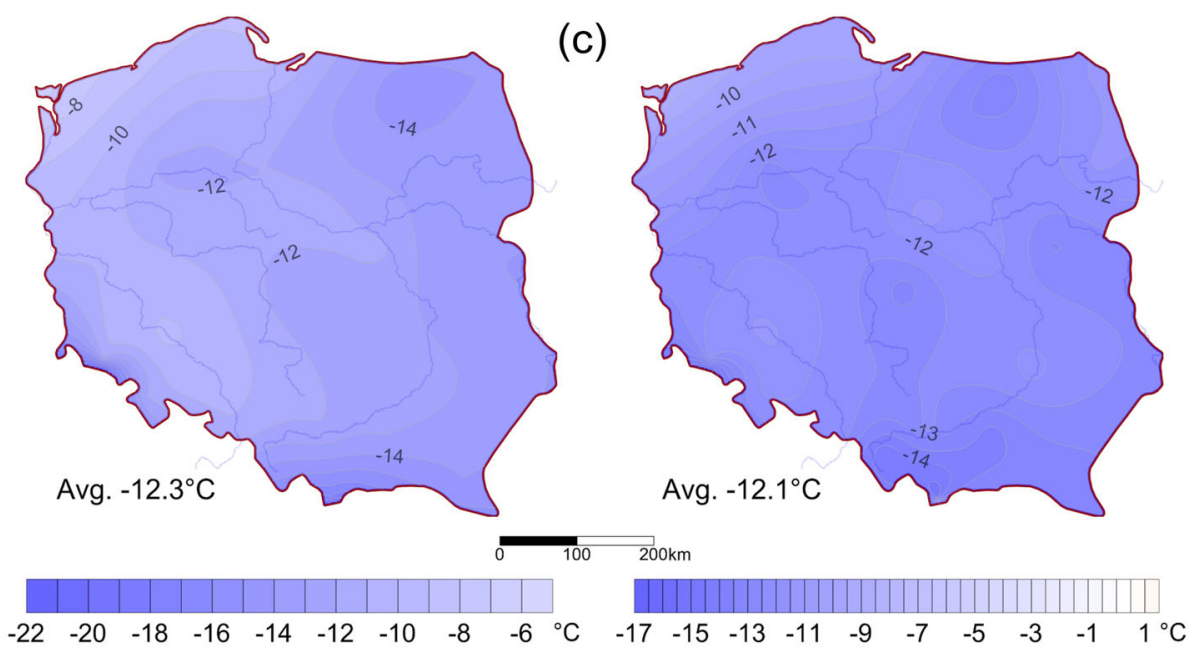

(d)

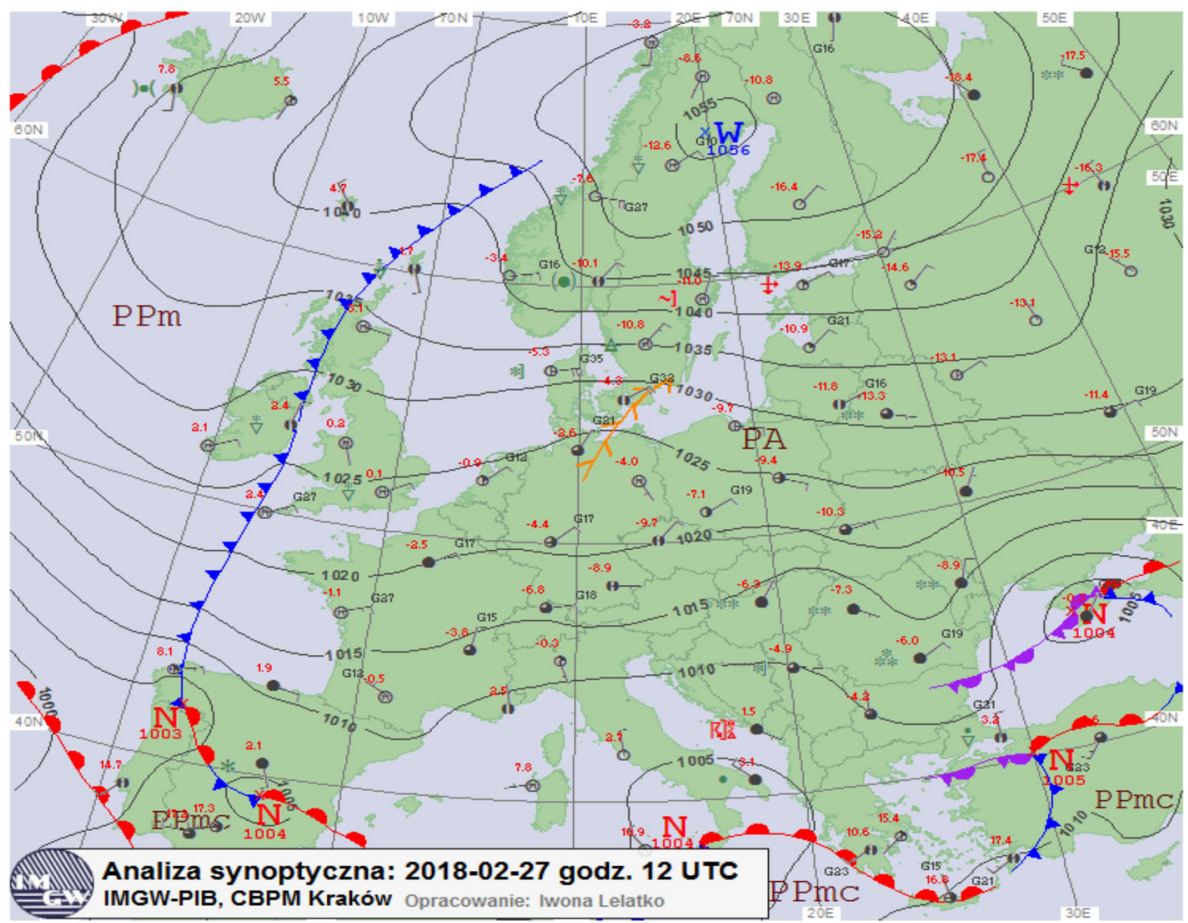

recorded in Opole, Bielsko-Biała, Lesko, Rzeszów, Raciborz, Wrockaw, and Sandomierz. On the analysed day, mean air temperature was higher than average by $4.5^{\circ} \mathrm{C}$ on Śnieżka to $11.8^{\circ} \mathrm{C}$ in Lesko. Anomalies above $11^{\circ} \mathrm{C}$ covered a major part of south-east Poland. In the analysed period, equally high anomalies were recorded on 5 and 6 November, and their maximum was observed on Kasprowy Wierch $11.8{ }^{\circ} \mathrm{C}$ (on 5 November). At the turn of October and November, a high 
Fig. 5 Anomalies of mean daily air temperature from 7 to 25 April (a) numbers of stations in accordance with numbers of stations in Table 1, arranged from northern to southern location), mean daily air temperature on 9 April (b) and its anomalies (c), and weather situation on 9 April (d); PA, arctic air mass; PPm, polar-maritime air mass; $\mathrm{PPk}$, polar-continental air mass; PZ, tropical air mass; W, atmospheric high; N, atmospheric low. Source of weather maps: Institute of Meteorology and Water

Management - National Research Institute (a)

25.04

23.04

21.04

19.04

$\frac{0}{\pi}$

17.04

15.04

13.04

11.04

09.04

07.04

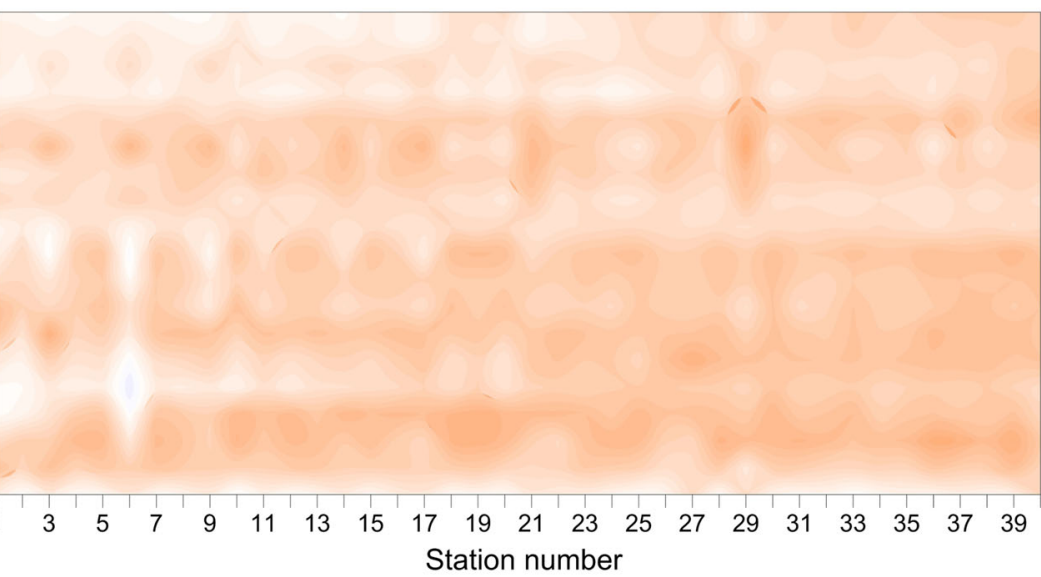

(b)

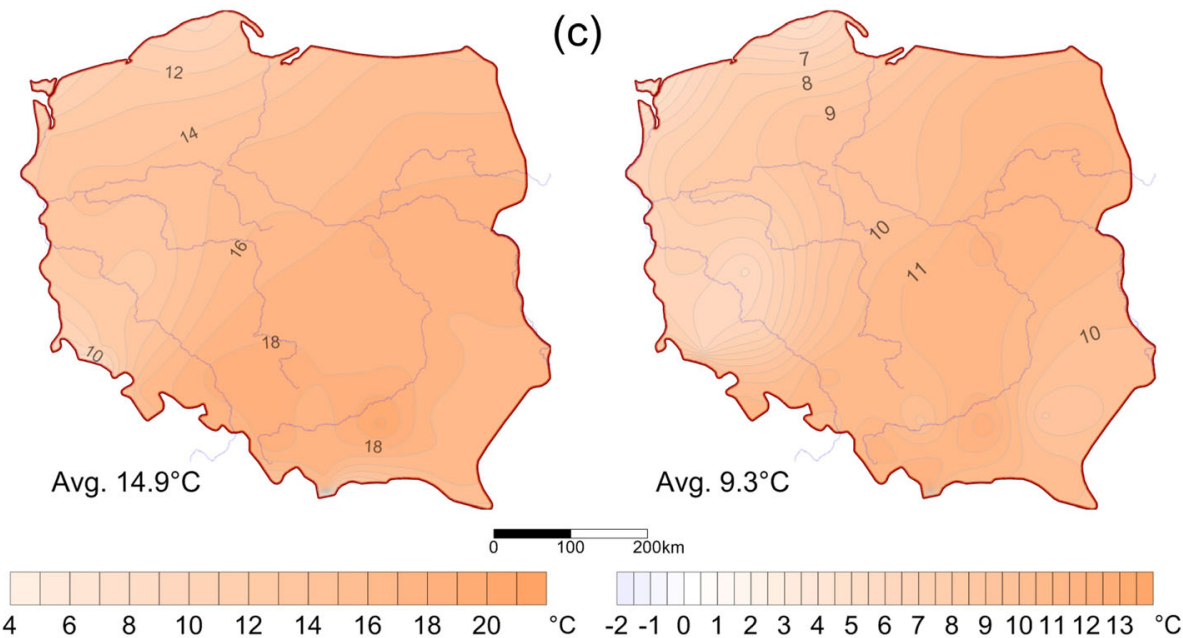

(d)

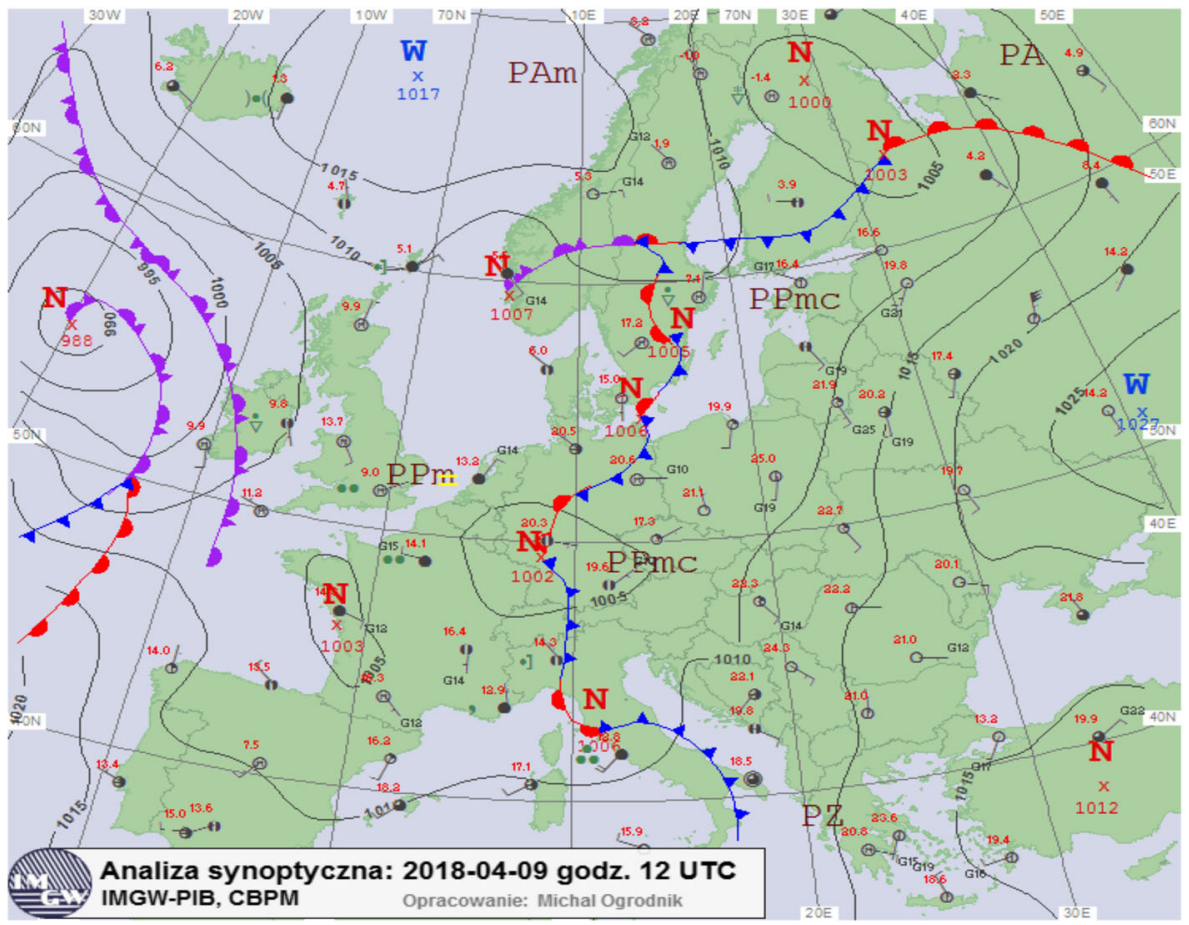


Fig. 6 Anomalies of mean daily air temperature from 29 October to 15 November (a; numbers of stations in accordance with numbers of stations in Table 1, arranged from northern to southern location), mean daily air temperature on 30 October (b) and its anomalies (c), and weather situation on 30 October (d); PA, arctic air mass; PPm, polarmaritime air mass; PPk, polarcontinental air mass; PZ, tropical air mass; W, atmospheric high; N, atmospheric low. Source of weather maps: Institute of Meteorology and Water Management - National Research Institute (a)

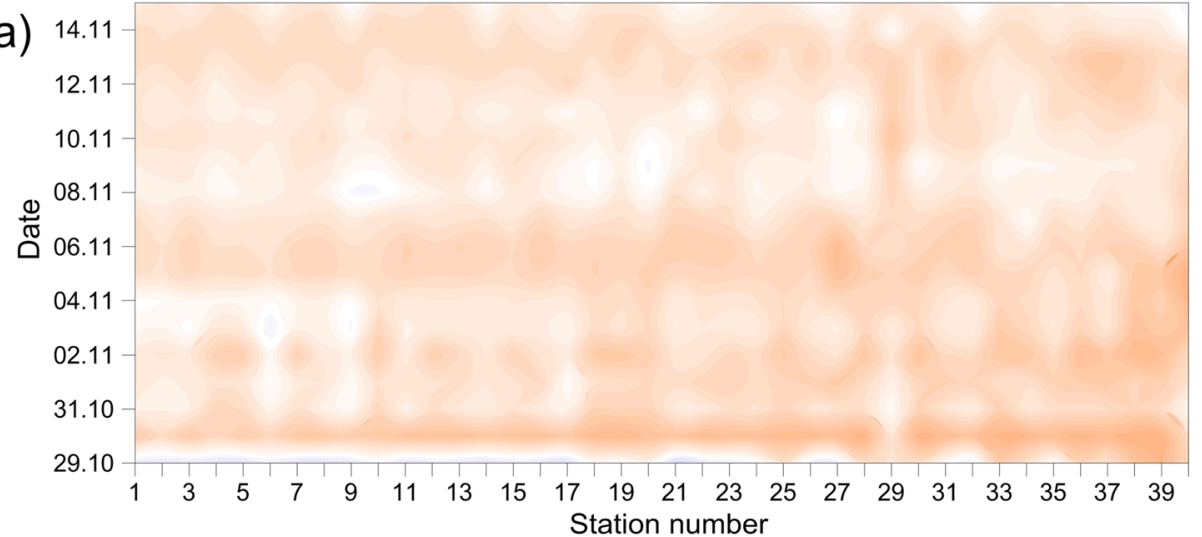

(b)
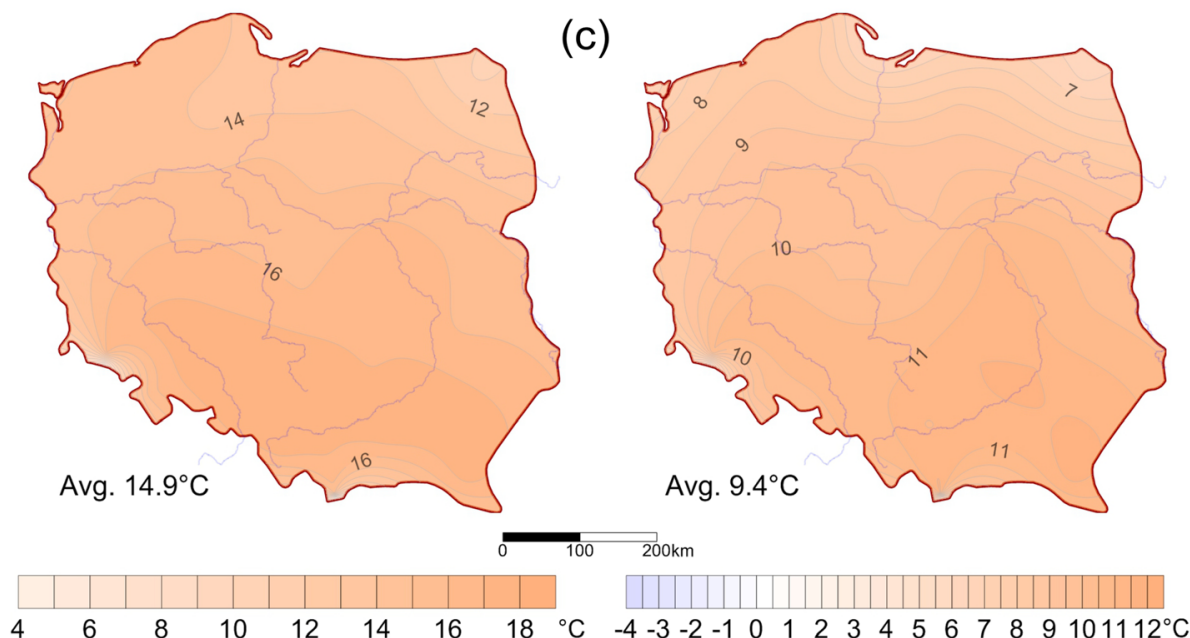

(d)

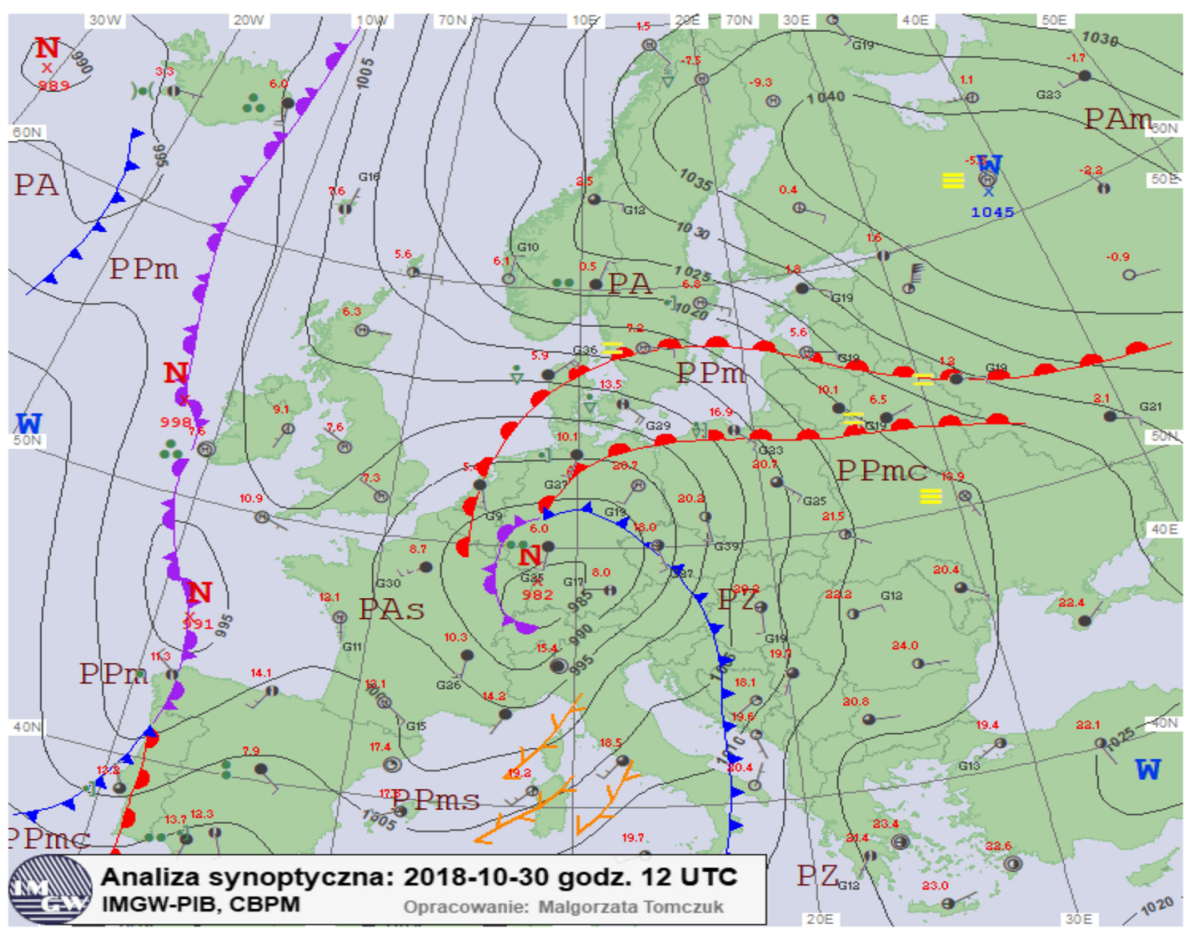


pressure system persisted over East Europe, with the centre over west Russia. Over the remaining area of Europe, low pressure systems moved from the south-west. On 30 October, Poland was under the influence of a low pressure system, with the centre over Benelux. The described baric situation caused the advection of warm tropical air masses. Around noon, a cool front entered over the study area from the south-west, followed by the advection of polar-maritime air masses. Somewhat lower air temperature in many stations was recorded on 11,17 , and 22 November.

\section{Discussion and summary}

The research revealed an increase in mean daily air temperature in the years 1966-2018. The recorded changes were statistically significant in the entire area, and the highest rates of changes were observed in the southern Poland with a maximum in Wrocław. A similar spatial distribution of changes was demonstrated by earlier research conducted in different time frames (Migała et al. 2016; Owczarek and Filipiak 2016; Tomczyk 2018). Kolednowicz et al. (2018) analysing thermal conditions in Poznań in the years 1848-2016 determined the rate of changes in air temperature at a level of $1.1^{\circ} \mathrm{C} / 100$ years, and over the last 30 years, it increased to a level of $4.6{ }^{\circ} \mathrm{C} / 100$ years. Stronger warming in recent years was also indicated by Kundzewicz and Huang (2010) analysing changes in air temperature in Potsdam (1893-2009).

Year 2018 was the warmest year in the analysed multiannual period over a major area (in $65 \%$ of stations). Its mean air temperature amounted in Poland to $9.5^{\circ} \mathrm{C}$. It was higher than the multi-annual mean value by $1.6^{\circ} \mathrm{C}$. The highest anomalies were recorded in the south of the country with a maximum in the south-west. Hoy and Hänsel (2019) evidenced that the analysed year was exceptional in terms of temperature, particularly in Central and Northern Europe, as manifested by early occurrence of heat waves and hot nights (tropical nights) which often persisted until October. Only in one-third stations analysed in this study, the highest mean annual air temperature was recorded in 2014 or 2015. Particularly year 2015 showed the record air temperature values in many regions (Hoy et al. 2017). It was also the year when numerous heat waves stroked Central Europe (Wibig 2018; Tomczyk and Bednorz 2019). During that summer, four heat waves occurred in Poland (Sulikowska et al. 2016). The longest one came in the first half of August, and in many stations, it was the longest since World War II (Krzyżewska and Dyer 2018).

In 2018, during only 2 months (February and March), mean monthly air temperature was lower than the multi-annual average. In the case of both months, the anomalies averaged $-2.5^{\circ} \mathrm{C}$, and the highest values of the anomalies were recorded at the turn of February and March. The highest positive anomalies were observed in April, when they averaged $4.6{ }^{\circ} \mathrm{C}$. The beginning of the month was particularly exceptionally warm, with the anomaly maximum on 9 April. In Germany, April and May were the warmest months since 1881 (Hoy and Hänsel 2019).

The study evidenced very high variability of thermal conditions in 2018, from strong frosts to a long period of high temperature throughout the study area. Such variability of thermal conditions can be associated with the variability of the North Atlantic Oscillation (NAO). At the turn of February and March, the negative phase of NAO was strongly manifested, resulting in considerable drops of air temperature. However, the positive phase was predominant throughout the year 2018 (based at NAO index from Climate Prediction Center, available at https:/www.cpc.ncep.noaa.gov/, Barnston and Livezey 1987). The NAO influence on the weather over the Atlantic and its neighbouring continents is most pronounced in the cold season, and it explains $36.7 \%$ of the variance in the winter, but only 22 . $1 \%$ in the summer (Barnston and Livezey 1987; Hurrell et al. 2003). This is mainly because of the seasonal variation of the oscillation strength and partly because of the seasonal changes in the spatial patterns of the NAO dipole centre locations (Barnston and Livezey 1987; Portis et al. 2001; Pokorná and Huth 2015). The summer NAO has a smaller spatial scale than its winter counterpart and both centres are shifted north, which means that the summer southern dipole is located over NorthWestern Europe rather than over the Azores-Spain region (e.g. Hurrell et al. 2003). Such anticyclonal blocking pattern over Europe in the positive NAO phase brings warmer-thannormal weather conditions over Europe, like in 2018.

Similar episodes of low and high air temperature were also recorded in earlier years both in Central Europe (Hoy et al. 2017; Tomczyk and Bednorz 2019) and in South Europe (Anagnostopoulou et al. 2017). According to several studies, extreme weather conditions in mid-latitudes can be associated with faster warming at higher latitudes than at medium latitudes (Arctic amplification). This results in an increase in the amplitude of Rossby waves and their slower movement southwards (Francis and Vavrus 2012, 2015; Cohen et al. 2014; Francis et al. 2017). The consequences are more permanent weather patterns at medium latitudes and higher possibility of the extreme weather conditions. Duchez et al. (2016) analysing the heat wave from 2015 evidenced that oceanic anomalies and the resulting strong southern SST gradient could have caused the expansion of a Rossby wave resulting in the stationary character of the Jet Stream, which translated into an increase in pressure and extreme air temperature over Central Europe. Extreme weather conditions in mid-latitudes, such as appeared in the 2018 year in Poland with cold spells in winter and-almost persistently - exceptionally warm other seasons, should be 
investigated in terms of all-encompassing Northern Hemisphere circulation patterns both at low- and middle- and hightropospheric levels.

Funding information This work was supported by the National Science Centre, Poland (grant number UMO-2017/24/C/ST10/00109).

Open Access This article is distributed under the terms of the Creative Commons Attribution 4.0 International License (http:// creativecommons.org/licenses/by/4.0/), which permits unrestricted use, distribution, and reproduction in any medium, provided you give appropriate credit to the original author(s) and the source, provide a link to the Creative Commons license, and indicate if changes were made.

\section{References}

Anagnostopoulou C, Tolika K, Lazoglou G, Maheras P (2017) The exceptionally cold January of 2017 over the Balkan Peninsula: a climatological and synoptic analysis. Atmosphere 8(12):252

Barnston A, Livezey R (1987) Classification, seasonality and persistence of low-frequency atmospheric circulation patterns. Mon Weather Rev 115:1083-1126

Barriopedro D, Fischer EM, Luterbacher J et al (2011) The hot summer of 2010: map of Europe. Science 332(6026):220-224

Cohen J, Screen JA, Furtado JC, Barlow M, Whittleston D, Coumou D, Francis J, Dethloff K, Entekhabi D, Overland J, Jones J (2014) Recent Arctic amplification and extreme mid-latitude weather. Nat Geosci 7:627-637

De Bono A, Peduzzi P, Giuliani G, Kluser S (2004) Impacts of summer 2003 heat wave in Europe. United Nations Environment Programme, UNEP

Deniz ZA, Uslan E (2018) Extreme cold air wave: January 2017. Gaziantep University Journal of Social Sciences 17(3):761-773

Dole R, Hoerling M, Perlwitz J, Eischeid J, Pegion P, Zhang T, Xu QT, Murray D (2011) Was there a basis for anticipating the 2010 Russian heat wave? Geophys Res Lett 38:L06702

Duchez A, Frajka-Williams E, Josey SA, Evans DG, Grist JP, Marsh R, McCarthy GD, Sinha B, Berry DI, Hirschi JJ-M (2016) Drivers of exceptionally cold North Atlantic Ocean temperatures and their link to the 2015 European heat wave. Environ Res Lett 11:07400

Francis JA, Vavrus SJ (2012) Evidence linking Arctic amplification to extreme weather in mid-latitudes. Geophys Res Lett 39:L06801

Francis JA, Vavrus SJ (2015) Evidence for a wavier jet stream in response to rapid Arctic warming. Environ Res Lett 10:014005

Francis JA, Vavrus SJ, Cohen J (2017) Amplified Arctic warming and midlatitude weather: new perspectives on emerging connections. WIREs Clim Change 8:e474

Gabriel KMA, Endlicher WR (2011) Urban and rural mortality rates during heat waves in Berlin and Brandenburg, Germany. Environ Pollut 159:2044-2050

García-Herrera R, Díaz J, Trigo RM, Luterbacher J, Fischer EM (2010) A review of the European summer heat wave of 2003. Crit Rev Environ Sci Technol 40(4):267-306

Grumm RH (2011) The Central European and Russian heat event of July - August 2010. B Am Meteorol Soc 92:1285-1296

Hoy A, Hänsel S (2019) Sommer ohne Ende: raum-zeitliche Bewertung der 2018er Hitzeepisoden in Europa im langzeitlichen Kontext. DACH2019 Abstracts. Available at: https://www.dach2019.de/ DACH2019-abstracts.pdf [Accessed 27th March 2019]

Hoy A, Hänsel S, Skalak P, Ustrnul Z, Bochníček O (2017) The extreme European summer of 2015 in a long-term perspective. Int J Climatol 37(2):943-962

Hurrell JW, Kushnir Y, Ottersen G, Visbeck M (eds) (2003) The North Atlantic oscillation. Climatic significance and environmental impact. American Geophysical Union Geophysical Monograph, Washington, p 134

Kolendowicz L, Czernecki B, Półrolniczak M, Taszarek M, Tomczyk AM, Szyga-Pluta K (2019) Homogenization of air temperature and its long-term trends in Poznan (Poland) for the period 18482016. Theor Appl Climatol 136(3-4):1357-1370

Krzyżewska A, Dyer J (2018) The August 2015 mega-heatwave in Poland in the context of past events. Weather 73(7):207-217

Kuchcik M (2001) Mortality in Warsaw: is there any connection with weather and air pollution? Geogr Pol 74(1):29-45

Kundzewicz ZW, Huang S (2010) Seasonal temperature extremes in Potsdam. Acta Geophys 58(6):1115-1133

Meehl GA, Tebaldi C (2004) More intense, more frequent, and longer lasting heat waves in the $21^{\text {st }}$ century. Science 305:994-997

Migała K, Urban G, Tomczyński K (2016) Long-term air temperature variation in the Karkonosze mountains according to atmospheric circulation. Theor Appl Climatol 125:337-335

Muthers S, Laschewski L, Matzarakis A (2017) The summers 2003 and 2015 in south-west Germany: heat waves and heat-related mortality in the context of climate change. Atmosphere 8:224

NOAA. 2019. Available at: https://www.ncdc.noaa.gov/sotc/global/ 201713 [Accessed 27th March 2019]

Otto FEL, Massey N, van Oldenborgh GJ, Jones RG, Allan MR (2012) Reconciling two approaches to attribution of the 2010 Russian heat wave. Geophys Res Lett 39:L04702

Owczarek M, Filipiak J (2016) Contemporary changes of thermal conditions in Poland, 1951-2015. Bulletin of Geography Physical Geography Series 10:31-50

Piniewski M, Mezghani A, Szcześniak M, Kundzewicz Z (2017) Regional projections of temperature and precipitation changes: robustness and uncertainty aspects. Meteorol Z 26:223-234

Pokorná L, Huth R (2015) Climate impacts of the NAO are sensitive to how the NAO is defined. Theor Appl Climatol 119(3-4):639-652

Portis DH, Walsh JE, El Hamly M, Lamb PJ (2001) Seasonality of the North Atlantic oscillation. J Clim 14:2069-2078

Rahmstorf S, Foster G, Cahill N (2017) Global temperature evolution: recent trends and some pitfalls. Environ Res Lett 12:054001

Rebetez M, Dupont O, Giroud M (2009) An analysis of the July 2006 heatwave extent in Europe compared to the record year of 2003. Theor Appl Climatol 95:1-2):1-7

Report of the Government Centre for Security (2016, 2017, 2018). Available at: http://rcb.gov.pl/zagrozenia-ocena-tygodniowa/. Accessed 27 March 2019

Sulikowska A, Wypych A, Woszczek I (2016) Fale upałów latem 2015 roku i ich uwarunkowania cyrkulacyjne (The 2015 summer heat waves in Poland and their synoptic background). Badania Fizjograficzne, Seria A Geografia Fizyczna 67:205-223 (in Polish)

Tomczyk AM (2018) Hot weather in Potsdam in the years 1896-2015. Meteorog Atmos Phys 130(1):1-10

Tomczyk AM, Bednorz E (2019) Heat waves in Central Europe and tropospheric anomalies of temperature and geopotential heights. Int J Climatol:1-17

UNWTO - World Tourism Organization, 2008. Emerging tourism markets - the coming economic boom, Press Release, UNWTO Madrid, 24 June 2008

Wibig J (2018) Heat waves in Poland in the period 1951-2015: trends, patterns and driving factors. Meteorol Hydrol Water Manage 6(1): $37-45$

Zacharias S, Koppe C, Mücke H-G (2015) Climate change effects on heat waves and future heat wave-associated IHD mortality in Germany. Climate 3(1):100-117

Publisher's note Springer Nature remains neutral with regard to jurisdictional claims in published maps and institutional affiliations. 